\title{
Black and White Propaganda Triggering the War in Afghanistan
}

\author{
Martin Asta Evans \\ Department of Asian Studies \\ Rutgers University \\ The United State of America \\ martinae@gmail.com
}

Citation: Evans, M. A. (2020). Black and white propaganda triggering the war in Afghanistan. Notion: Journal of Linguistics, Literature, and Culture, Vol 2(2), p. 80-89. DOI: http://doi.org/10.12928/notion.v2i2.2862

\begin{tabular}{l|l}
\hline \multicolumn{1}{c}{ Article Info } & \multicolumn{1}{c}{ ABSTRACT } \\
\hline $\begin{array}{l}\text { Article History } \\
\text { - Article Received }\end{array}$ & $\begin{array}{l}\text { Lone Survivor Film highlights on the American propaganda in Afghanistan war. In } \\
\text { analysing the topic, the writer has two objectives of the research. They are to analyse } \\
\text { the American propaganda in Afghanistan war and to describe the situation of } \\
\text { th October 2020 } \\
\text { - Article Accepted } \\
5^{\text {th }} \text { November 2020 } \\
\text { interdisciplinary approach, as it applies American multidisciplinary studies. The } \\
\text { writer uses descriptive qualitative method to analyse the data adopted from the } \\
\text { scenes and dialogues of the film Lone Survivor. The result of this research is that } \\
\text { propaganda in the film Lone Survivor can be classified into black and white } \\
\text { propaganda. The black propaganda is shown as American pretends to have noble } \\
\text { heart in some scenes in the film, in contrast with the truth that they have hidden } \\
\text { agenda. Those are to change the audience's view about America. The white } \\
\text { propaganda in the film is shown when American tries showing to the world that } \\
\text { there is some bad fact about Ahmad Shah group. Also there are some interesting } \\
\text { situation between American soldiers and Taliban rebels which are found in Lone } \\
\text { Survivor film. }\end{array}$ \\
$\begin{array}{l}\text { Ailm } \\
\text { prophanistan war }\end{array}$ \\
$\begin{array}{l}\text { America } \\
\text { black and white }\end{array}$
\end{tabular}




\section{Evans, Martin Asta \\ Black and White Propaganda Triggering the War in Afghanistan}

\section{INTRODUCTION}

War becomes part of human history. Since the end of the cold war, both the frequency and deaths caused by the war s decreasing, especially in the international system as the changes $\mathrm{n}$ the characteristics of the war. War $\mathrm{n}$ the modern era has been affected by globalization. The nature of the war s unchanged, but ts shape reflects the times and the specific environment $\mathrm{n}$ which the war $\mathrm{s}$ going on. War $\mathrm{s}$ needed a highly organized society[1][2].

War is still an nteresting ssue as a phenomenon $\mathrm{n}$ America. Even, war cannot be perished $\mathrm{n}$ the world. America, known as a super power country, s viewed from the strength of ts military defense[1]. It is facilitated with the best weapons and the advanced technology. Within each year, America works up the budget for funding the military weapons that s why American military almost on each state has a military base. It means that the American military dominates into spears or political regulator globally. All regulated forms by government policies with the American military aim to maintain the peace and freedom over the countries for and to expand democracy ideology[3].

One of the American roles in relation to the war can be seen in Afghanistan war. The U.S. was supported initially by the United Kingdom and Canada and later by a coalition of over 40 countries, including all NATO members[4]. The war's public aims were to dismantle al-Qaeda and to deny it a safe base of operations in Afghanistan by removing the Taliban from power. Three thousand people has been killed by the hijacked of al-Qaeda terrorists in World Trade Center in New York City and The Pentagon near Washington, D.C on 11 September 2001. in response, the Bush government launched the global war against terrorism, attacking Afghanistan, removing the Taliban government and hunt down alQaeda training camps.

Afghanistan war is the longest war in American history. According to American free press, the war in Afghanistan, has become a forgotten war that has cost taxpayers trillions of dollars. As the fighting grinds on, there are increasing reports that U.S. military leadership is in disarray, leaving soldiers, who are stationed there, wondering what they are even doing in the mountainous country. In addition, according to experts on the war, such as Bill Roggio, the editor of the online blog "The Long War Journal," which tracks the Taliban in Afghanistan, the Taliban "probably either controls or heavily influences half of the country."

The topic of Afghanistan war is interesting to be discussed in American perspective. One of the evidences is shown in the film work. Lone Survivor film by Petter Berg is one of them which tells about the phenomena of Afghanistan war[5]. This film brings the story of Marcus Luttrell, one of American Naval, who experienced the war. Through Lone Survivor, the researcher saw the struggles of American naval that joined the Navy Seal. One day Marcus and his three friends were assigned to carry out the mission to kill Ahmad shah, but this mission is known by inhabitant of Taliban. Finally, this mission failed and three of Marcus's friends were died in that mission. Marcus was saved by Gulab, a citizen of Afghanistan. Marcus tried to send a letter to the US, but the mission was known by Taliban. The Taliban also wanted to lynch Marcus. The US forces comes at the right time so that Marcus could be saved even though Ahmad Shah cannot be captured[5].

The researcher would like to analyze the Lone Survivor film by Peter Berg because the film s ncreasing which mainly shows struggles $\mathrm{n}$ war. The researcher $\mathrm{n}$ this study focused on the American propaganda $\mathrm{n}$ Afghanistan war and the portrayal situation during Afghanistan war.

\section{Popular Culture}

Popular culture consists of two words, "popular and culture" which focuses on "culture". Culture is one of the two or three most complicated words in the English language[6][7]. William also gives three widely definitions in "culture". Firstly, culture can be used in the general process as the intellectual, spiritual, and aesthetic. Secondly, the culture may suggest certain way of life, whether of people, period or group. At last, culture is to what the structuralists and post-structuralists called signifying practice[8].

Popular culture is a culture evolved by following the change of times and influenced by the 
communications industry such as film, television, news media and the advertising industry. Besides popular culture as well as the mass media, popular culture is a culture that comes from a lot of people in the world. Popular culture refers to mass culture with constructing a culture to be commercial popular culture. it intends to mass production for production for mass consumption which means audiences are the consumers[8].

Popular culture is creative work of art whether painting, music, film produced to entertain. The characteristics of popular culture are written or transmitted by print, broadcasting or other commercial, not serious concept or idealism, individual work mass produced to give pleasure, financial gain and popularity become the goals, patented in the form of popular literature, popular songs, popular art.

Film as a kind of literary work has all artistic elements of literature before, like novel, drama, painting, music, dance, photography, and other literary works[9]. Literature and film the narrating discourse appears to provide the truth the real transparently. While the materiality of the other discourses is acknowledged, that of metalanguage is not[10].

In watching a film, spectator is not merely a passive receptacle imbibing its meaning, but is engaged in succession of interpretations which depend on a whole set background beliefs and without which the film would not make sense. On the basic of such beliefs or theories, whether formalized or not, the spectators see faces, telephones, desert landscapes rather than patches of color; ascribes motive to characters; judges certain action as good and others as bad, decided that the film is realistic and that one is not; distinguishes the happy from the unhappy ending.

Film is correlated with Popular Culture in America[9]. The popular culture is so wide to discuss that The researcher wants to see popular culture which is reflected on film as literary works, only. Film is moving picture: film illustrates the human life and the environment. it is made to be used because it is product of technology. Film is considered the youngest art form and has inherited much from the order and more traditional arts. Some films do present a critical view of American culture, political corruption, or greedy capitalism, through of in a satirical or humorous way, and with a happy ending, so that the audience doesn't become too depressed and refuse to pry an unhappy experience[11].

There are some kinds of culture; high culture, folk culture and pop culture, high culture is creating work of art that always written. The characteristics of high culture are written, creative with both conceptual and theory as well as talent, individual work. Creative for an ideal, acquisition of money is not the chief goal, recorded in the form of high literature, fine art article music. Folk culture is creative work of art from traditional culture that never written from generation to generation[12].

The characteristic of folk culture is handed down orally (legend, tales), it is creation by tradition and hearsay, handed from generation to generation, anonymous, creative to give moral express people's suppression suffering as well as, community equilibrium it the chief goal, unrecorded, except in the memories and habits of the common people themselves, in the form of legend tales, songs, belief, namely wisdom commonly ways of speaking, and the last is popular culture. Popular culture is creative work of art whether painting, music, film produced to entertain.

Popular is seen from people's point of view the people and not from who looking for some agreement or power on them[13]. Nevertheless, the first definition is not dying. Popular culture is not identified by people but somebody else and still has two old meaning: inferior work (popular culture, popular press which is differentiated from quality presses); and work with made deliberately in order to be like by people. (Popular journalism is differentiating with democratic journalism, or popular entertainment); yet modern definition which is liked by many people, of course in many cases over lapped 


\section{Evans, Martin Asta \\ Black and White Propaganda Triggering the War in Afghanistan}

with old definition also is one of important modern pressure.

Some Characteristics of popular culture are to give pleasure and entertainment. And the financial gain popularity become the goals. Storey stated, popular culture is a mass produced, transmitted by print, broadcasting and other commercial evidences, it is audience is a mass of undiscriminating consumes [8]. Bullock and Trombly say "popular culture has since become understood in term of active process and practices as well as objects and artifacts and encompasses a variety of phenomena including mail order, catalogues, the design of cars and other consumer durables, clothes, food, fashion, football machines, video tapes, Chrismas, etc"[14].

\section{Propaganda Theory}

By borrowing Jowett \& O'Donnell's thought, "Propaganda is defined to give a message and suggest, it contains negative and dishonest contents. Propaganda frequently is used as lies, distortion, deceit, manipulation, mind control, psychological, sociological, brainwashing, and palaver through mass media "film". The terms propaganda and persuasion have been used interchangeably in the literature on propaganda, as well as in everyday speech[15].

Propaganda employs persuasive strategies, but it differs from persuasion in certain purpose"[16]. Jowett and O'Donnell also added despite the enormous inherent appeal of film, even, popularity of film as one of the world's great entertainment forms as a medium of information. "Of all the mass media, film has the greatest potential for emotional appeal to its audience, offering a deeper level of identification with the characters and action on the screen than found elsewhere in popular culture". in short, it has the ability to evoke an immediate emotional response, seldom found in the other mass media. Yet, systematic attempts by governments or other groups to use the motion picture as a major channel for the delivery of deliberate propagandistic messages have not, on the whole, but been very successful seen in a film[16].

In this research, the researcher saw some efforts of American propaganda through mass media such as film, and film is one of the best ways to spread propaganda to society as reflected in a film. According to Halling[17], there are "four reasons for media as propaganda. First, the America excels in films and Hollywood was having its golden age during World War iI and now. Second, film is the most effective propaganda weapon. Third, the medium of film is a visual medium that also uses sound. This makes it excellent as a propaganda medium, allowing the propagandists to influence people with both auditory and visual information. Most other propaganda mediums are only able to use one of these ways. Fourthly, the medium of film is very interesting and liked by many people".

The propaganda in this film appears to have a clear purpose and certainly an explicitly stated conclusion, but the true purpose is likely to be concealed. in other words, propaganda may appear to be informative communication when ideas are shared, something is explained, or instruction takes place. information communicated by the propagandist may appear to be indisputable and totally factual. The propagandist knows, however, that the purpose is not to promote mutual understanding but rather to promote his or her own objectives. Thus, the propagandist will attempt to control information flow and manage a certain public's opinion by shaping perceptions through strategies of informative communication. in this Lone Survivor film, persuaders, tries to appear as information about this film. An effective persuader makes the purpose as clear as possible to bring about attitude or behavior change. "The explicitly stated conclusion is twice as likely to get the desired audience response compared with the suggested one". Propaganda is a form of communication and how it uses both informative and persuasive communication concepts to promote its own objectives by controlling the flow of information, managing public opinion, and manipulating behavioral patterns through a film. "Propaganda is a subset of both information and persuasion". Some techniques with information and persuasion are going to beyond their aims. Propaganda does not seek mutual understanding or mutual fulfilment of needs. "Propaganda deliberately and systematically seeks to achieve a response that wants by propagandist"[16]. 


\section{Forms of Propaganda}

According to Jowett and O'Donnell, at first, it may not seem difficult to determine how propaganda in the media. The analyst examines which media are being used by the propagandist. "Modern propaganda uses all the media available press, radio, television, film, the internet, posters, handbills, buttons, billboards, speeches, flags, street names, monuments, coins, stamps, books, plays, comic strips, poetry, music, rituals, museum displays, sporting events, cultural events, and awards and prizes". The various messages come from the same source via the media need to be compared to determine any consistency of apparent purpose. All output will be tied to ideology in one way or another. Describing the media usage alone is insufficient in drawing a picture of media utilization, for the analyst must examine the flow of communication from one medium to another and from media to groups and individuals[16]. Jowett and O'Donnell (2012), they said that; "The main focus should be on how the media are used. The propagandist might show a video and hand out leaflets afterward. This type of practice maximizes the potential of the media"[16].

According to Szanto, although propaganda takes many forms, it is almost always in some form of activated ideology. "Sometimes propaganda is agitative, attempting to rouse an audience to certain ends and usually resulting in significant change; sometimes it is integrative, attempting to render an audience passive, accepting, and nonchallenging"'[18].

There are three forms of propaganda. According to Jowett and O'Donnell[16] in Propaganda and Persuasion there are three forms of which are categorized based on the methods it is used to shape its argument, such as; black, gray, or white.

\section{a. Black Propaganda}

Black propaganda is when the source is concealed or credited to a false authority and spreads lies, fabrications, and deceptions. Black propaganda is the "big lie," including all types of creative deceit. Joseph Goebbels, Hitler's propaganda minister, claimed that outrageous charges evoke more belief than milder statements that merely twist the truth slightly. The success or failure of black propaganda depends on the receiver's willingness to accept the credibility of the source and the content of the message. Care has to be taken to place the sources and the messages within a social, cultural, and political framework of the target audience. if the sender misunderstands the audience and therefore designs a message that does not fit, black propaganda may appear suspicious and tends to fail[16].

\section{b. Grey Propaganda}

Grey propaganda is somewhere between white and black propaganda. The source may or may not be correctly identified, and the accuracy of the information is uncertain[16].

\section{c. White Propaganda}

White propaganda comes from a source that is identified correctly, and the information in the message tends to be accurate. in the shape of this propaganda, source of propaganda conveys clearly and openly, propaganda is often called a model of overt propaganda and also commercial propaganda. This is what one watched, although what viewers see in this film is reasonably close to the truth, it is presented in a manner that attempts to convince the audience that the sender is the "good guy" with the best idea and political ideology. White propaganda attempts to build credibility with the audience, for this could have usefulness at some points in the future[16].

Along with the preceded description, the researcher uses a white and black propaganda theory to analyze the object of the research. White propaganda is applied to know obvious actions by the Americans in winning the war. in other side black propaganda is to find some evidences of secretive mission of Americans in war tactics.

\section{History of Afghanistan war}

The present situation in Afghanistan is quite problematic. The country has very little in the way of existing infrastructure, and no real prospects for economic growth aside from the illegal drug trade. The central government's power is limited to Kabul, 


\section{Evans, Martin Asta \\ Black and White Propaganda Triggering the War in Afghanistan}

and it is almost entirely dependent on US-led forces for security. Civilian casualties have increased rather than decreased in recent years, and there are few signs that Afghanistan is anywhere near becoming a safer place (Amnesty international). Taliban and al-Qaeda forces established strongholds in parts of Afghanistan and over the border in Pakistan. Taliban fighters have launched attacks on major urban areas in Pakistan, including the city of Lahore[19]. They have also made incursions into the Punjab region, which borders india. Taliban and al-Qaeda commanders have asserted that they plan to continue to increase their presence in Pakistan, and use that country as a base for launching attacks against the United States and its allies. US efforts to eliminate Taliban and al-Qaeda leadership through precision missile strikes have had some limited success, but have also motivated ordinary Pakistanis to speak out in opposition to US interference[20].

Some argue that the regional situation is so unstable that the US will have to remain in Afghanistan, and possibly Pakistan, for many years to come. Plans are in place to double the number of US troops on the ground in Afghanistan in 2009, but it is unclear whether or not this will noticeably improve the security situation in the region. Furthermore, some are concerned that the US, which encouraged the Mujahideen to enmesh the Soviets in an Afghan trap, is now finding itself mired in the same situation that caused so much political damage to the Soviet Union.

\section{METHODOLOGY}

In this research, the researcher applied qualitative research as the way to accumulate the data and to explain the data. By using descriptive technique, accurate and detail information can be gained. Strauss and Corbin[21] broadly defined that, "Qualitative research means any kind of research that produces findings not arrived at by means of statistical procedures or other means of quantification." The researcher used one primary source, which was Lone Survivor film by Peter Berg and supported by some sources taken from books, and articles.

The researcher applied two ways of collecting data. First, the researcher collected the data from the library. To collect and complete the qualitative data, the researcher watched Lone Survivor film, read the history of Afghanistan war and a brief account of film. Second, the researcher identified, defined and made notes on the important facts that gave clearer information about the film and Afghanistan war.

By having the data, the researcher interpreted them to figure out the phenomenon of Afghanistan war presented in the film. This paradigm guided the result and discussion into a certain conclusion.

\section{RESULT AND DISCUSSION}

In this chapter, the researcher discusses the problem which was already determined before. The discussion focuses on Propaganda in Lone Survivor film. The writer separates each point of discussion in order to give the detail explanation and insert some quotations of scenes and dialogues along with pictures captured from this film to support the truth of this discussion.

To understand this research, the writer uses interdisciplinary approach. it is meant, approach needs many points of view in this research. The writer wants to explain the theories which have correlation in this film, and then those theories will be implemented to support this research. First, theory that the writer used is Popular Culture, because this film is included in Popular Culture product. Second is propaganda theory. in this part, the writer wants to represent the kinds of propaganda in Afghanistan war as seen in the film Lone Survivor. The third is the situation of Afghanistan war as seen in Lone Survivor film. Here the researcher uses the study of Afghanistan war history.

a. Propaganda in Use

The functions of propaganda are as "attempts to move a recipient to a predetermined point of view by using simple images and slogans that truncate thought by playing on prejudices and emotions". Jacobs separates propaganda from persuasion according to the type of deliberation which is used to design messages. Persuasion is based on debate, discussion, and careful consideration of options to discover "better solutions for complex problems," whereas "propaganda results in the manipulation of the mob by the elite"[22]. 
Based on theory above, the researcher focuses on military strategy as the central attention. How the importance image of the military strategy in American propaganda tools are related to propaganda theory reflected in the film?

1) Black propaganda

There are some evidences that show black propaganda by American soldiers as seen in the film Lone Survivor. They are described below.

$\begin{array}{ll}\text { Marcus } & \text { : I cannot. } \\ \text { Axe } & \text { : This is a gentle solution. } \\ \text { Marcus } & \text { : You want to enter Leavenworth? } \\ \text { Danny: } & \text { : You do not know how many pilgrims are } \\ & \text { there? } \\ \text { Axe } & : \text { Do not let him influence you. } \\ \text { Danny } & : \text { Marcus I just said, you do not .... } \\ \text { Axe } & : \text { Look at the boy, open your mind do not be } \\ & \text { influenced by him. kill them, this murphy is } \\ & \text { your power. } \\ \text { Murphy } & : \text { I do not want to vote. This is not an option. } \\ & \text { This is what we will do. This operation has } \\ & \text { been decided. Clear the things. We let them } \\ & \text { off and climbed to the top. When at the top, } \\ & \text { you connect communication. if connected, } \\ & \text { we ask for pick-up and go home. (00.46.29) }\end{array}$

From the dialogues, American soldiers are in a secret mission in the hill. But their presence is known by some Taliban villagers who are shepherds. This film clearly shows black propaganda as it is a portray how honorable American soldiers release the shepherds. in their view, soldiers like them are prohibited to kill barefaced people. in fact, American soldiers are bad people for they sneak into other countries territory in order to kill someone that they hate much. To save eyewitness is impossible for them because it may harm their secret mission.

\section{2) White Propaganda}

There are some evidences that show kind of white propaganda by American soldiers as seen in the film Lone Survivor. They are described as below.

The scene on film, 01:38:32, shows the villagers help Marcus while he was almost murdered by one of Taliban rebel group. Marcus then is brought to the village to have treatment. But the Taliban rebel group find his shelter and goes to kill him. But in surprise they were fought by the villagers. Here the film dramatizes the scene by showing assassination by Taliban rebel group toward the villagers. This aims to make an audience view that Taliban rebel group is bad and evil.

\section{b. Situation of Afghanistan War}

Lone Survivor tell about true story of American military operations in Afghanistan with a Red Wing operation code. The mission is to capture or kill a senior Taliban commander named Ahmad Shah. Ahmad Shah and his troops killed at least 20 people a week. A living witness named Marcus Ruttrell in 2007 tells his story in a film called Lone Survivor.

These are dialogues showed situation of Afghanistan war as reflected in film to support the analysis.

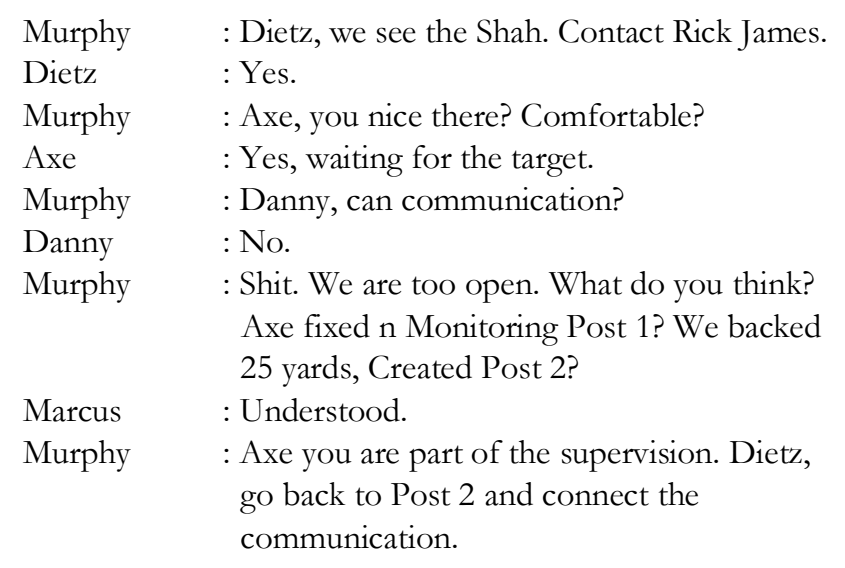

Based on dialogues above, the four members of the Navy Seal team named Marcus Ruttrell (Mark Wahlberg), Matthew Axelson (Ben Foster), Michael Murphy (Taylor Kitsch) and Danny Dietz (Emile Hirsh) depart from Bagram air base to a village surrounded by hills dentified the existence of Ahmad Shah. They are already on the penalty spot to shoot Ahmad Shah who is physically possessed with no ears. Unfortunately, disrupted communication links so that the confirmation command is not obtained. (Source: Lone Survivor film: 00:31:01)
Marcus
Axe
: cannot.
Marcus
: This s a gentle solution.
Danny:
: You want to enter Leavenworth?
Axe : Do not let him nfluence you.
Danny : Marcus just said, you do not .... 


\section{Evans, Martin Asta Black and White Propaganda Triggering the War in Afghanistan}

\begin{abstract}
Axe
: Look at the boy, open your mind do not be nfluenced by him. kill them, this murphy s your power.

Murphy : do not want to vote. This s not an option. This s what we will do. This operation has been decided. Clear the things. We let them off and climbed to the top. When at the top, you connect communication. f connected, we ask for pick-up and go home.
\end{abstract}

Based on dialogues above, suddenly appeared three goatherds. Of course this is unexpected. inevitably the Americans arrested him and this is where the debate arises what to do with them. The first alternative is to kill them with the consequences of current tasks but also make them offenders. The second alternative is to let them go and the task fails because the existence of the operation is already known by others. in here, their conflicts, thoughts and reasons are quite acceptable in debate. As the head of the mission Marcus to decide the outcome and voting does not apply. So every leader is the right to make any decision. (Source: Lone Survivor film: 00:43:35)

$\begin{array}{ll}\text { Marcus } & \text { : No, no, no! Let me go! No! No! do not } \\ & \text { want! Fuck you! } \\ \text { Faraq } & : \text { Fuck you, America, Gentiles! Mengaisla, } \\ & \text { damn t! } \\ \text { Marcus } & : \text { Do t! Do t! Do t! Fuck! Fuck! Fuck! } \\ \text { Faraq } & : \text { Will take your head and send t to America } \\ & \text { yes, fuck you! }\end{array}$

Based dialogues above, Gulab wants to cut off Marcus's head on how to hate Taliban forces to Americans. Besides, Gulab and his friends are trying to save Marcus. So, in here everyone has the right to keep what they think is right. (Source: Lone Survivor film: 01:38:32).

The black propaganda in the film Lone Survivor is depicted into four evidences which are supported by some scenes and dialogues. The first evidence is bad statement about Ahmad Shah, the Taliban's leader, that he is a bad person. It shows in the scene when American soldier are planning their tactic to kill Ahmad Shah in Taliban. The second evidence shows the brutality of Ahmad Shah's group who kills villagers. It is proved in the scene when Taliban group, leads by Ahmad Shah, kills innocent people. Actually, Ahmad Shah's group is a guardian, not a radical group. The third evidence is the film shows fake noble of American soldiers in releasing Taliban shepherds. It shown by the way they let Taliban shepherds, which are the eyewitness, to be freed. The fourth evidence is the film shows impossible gratefulness of American soldier toward Taliban kid. it shown by the main character kisses the boy who help him.

The white propaganda in the film Lone Survivor in five evidences. The first evidence shows when four American Navy Seal soldiers are sent to complete America's mission to kill Ahmad Shah in Taliban. The film tries to give a message to the audience that American people are strong, because they only send four soldiers in the dangerous mission. The second evidence is America has sophisticated weaponry and war transportation. Some scenes show that American soldiers are sent by war plane to Taliban, they are supported by modern guns. The third evidence is Ahmad Shah's group bravely attacks Taliban villagers to find Marcus. It is shown dramatically to make bad view of Taliban group toward the audience.the next evidence is Ahmad Shah's group burns the villagers houses and building to make them surrender. it show that the film tries to make Taliban rebel group as brutal group. The fourth evidence is the die of Taraq during the war. it show that the film tries to imagine Taraq as antagonist character and Marcus is hero. The last evidence is the American soldiers' teamwork. Some scenes in the film show that the four American soldiers are responsible and care each other. They survive together during the Ahmad Shah's group attack in the mountain side. Some scenes try to give a message that although they were at risk, they still pay attention towards the teamwork and struggle to rescue together

The second point of the result is the war situations between America and Taliban as seen in Lone Survivor film. Those are a very tense situation for America which shows the struggles of four American navy seals against the Taliban. They are on a mission to kill the leader of the Taliban, but eventually three of the navy seals are killed in this mission and only survivors Marcus. They are shown in eight evidences. The first plot is The American soldiers are sent secretly to Taliban.then, the soldiers have lost in communication. Next, the American soldiers are 
found by local shepherds. Then, the American soldiers are sieged by Taliban rebel group in large number. During Ahmad Shah's group attack, American soldier struggles to save themselves for they fail to call the help. American soldiers are suffered, and three of them are died. Marcus, the survivor is saved by Gulab, one of the Taliban's villagers. The next plot is Taliban rebel group makes a war with the villagers to catch Marcus. The final plot in the film is American soldiers comes at the right time to save Marcus.

The writer finds out that war and propaganda are related, which both have the same impact to influence and define the target. War may use propaganda as a tool to achieve the U.S. missions, and the overt propaganda may lead to the armed conflicts and rebellions. In addition, the strategy of American military uses propaganda mission. America is a country with high propaganda tactic. By economy and political reasons, specifically a company uses unusual thing to get profit. Film is one of tools to run the propaganda. Through film, America enters some elements to implement the American ideology in the film. There are several things that can be used as propaganda tools like superhero figure and technology effects. in this case, America uses strategy as its element to imply its ideology so the audiences hoped can be influenced by the film.

\section{CONCLUSION}

From the discussion, the researcher concludes that propaganda is defined to give a message and suggest, it contains negative and dishonest contents. There are some interesting findings between American soldiers and Ahmad Shah's group which are found in Lone Survivor film, including analysis propaganda on Afghanistan war and description of the Afghanistan war situation as seen in Lone Survivor Film.

The writer finds the first point of the result, which is propaganda values. The writer includes some propaganda actions which are portrayed in the film Lone Survivor, between the American military soldiers and Ahmad Shah's group in Taliban. According to the analysis, those propaganda actions are aimed to give a good message about America towards the audiences. Based on Jowett and O'Donnell theory, some evidences of propaganda are classified nto wo forms, which are black and white propaganda.

\section{REFERENCES}

[1] Levy, J. S., \& Thompson, W. R. (2011). Causes of war. Oxford: John Wiley \& Sons. http://slantchev.ucsd.edu/courses/ps143a/read ings $/$ Levy $\% 20 \& \% 20$ Thompson $\% 20$ $\% 20$ Causes $\% 20$ of $\% 20$ War.pdf

[2] Boggs, C. (2017). The Hollywood war machine: US militarism and popular culture. Routledge. https://www.taylorfrancis.com/books/9781315 $\underline{086279}$

[3] Tur, A. P. A. \& Sari, F. A. (2019). Reshaping the society face through the culture of horror told $n$ Shirley Jackson's the lottery. Notion: Journal of Linguistics, Literature, and Culture, Vol. 1(1), May 2019. https://doi.org/10.12928/notion.v1i1.709

[4] Chiozza, G., \& Goemans, H. E. (2011). Leaders and nternational conflict. Cambridge: Cambridge University Press.

http://slantchev.ucsd.edu/courses/ps240/08\%2 0Leaders $\% 20$ as $\% 20$ Units $\% 20$ of $\% 20$ Analysis/C hiozza $\% 20 \& \% 20$ Goemans $\% 20$ $\% 20$ Leaders $\% 20$ and $\% 20$ International $\% 20$ Confli ct $\% 20[\mathrm{Ch} \% 201-4]$.pdf

[5] Osanloo, A., \& Grant, C. (2016). Understanding, selecting, and ntegrating a theoretical framework $\mathrm{n}$ dissertation research: Creating the blueprint for your "house". Administrative ssues journal: connecting education, practice, and research, 4(2), p. 7. https://aij.scholasticahq.com/article/7.pdf

[6] Kafi, Z., \& Motallebzadeh, K. (2016). An ntroduction to sociolinguistics. nternational Journal of Society, Culture \& Language, Vol. 4(2), p. 134-140. http://www.ijscl.net/article 14429 25be808ac7 cd2c02504dc83e945f8909.pdf

[7] Delani, S. (2019). Manipulative Leadership and The Effect towards ts Subordinate as Portrayed $n$ Orson Scott Card's Novel. NOTION: journal of Linguistics, Literature, and Culture Vol 1(2), p. 
27-34.

https://doi.org/10.12928/notion.v1i1.713

[8] Storey, J. (2012). Cultural Theory and Popular Culture An ntroduction: A Reader, $\left(\sigma^{\text {th }}\right.$ ed). Harlow: Pearson Education.

[9] Wasson, H. (2015). Formatting Film Studies. Film Studies, 12(1), p. 57-61. https://www.academia.edu/download/4849434 0/Wasson Formatting Film Studies.pdf

[10]Eagleton, T. (2011). Literary theory: An ntroduction. John Wiley \& Sons.

http://marul.ffst.hr/ bwillems/fymob/ch5.pdf

[11]Barnes \& Nobles. ( 1991). New American encylopedia, Vol. , V, XIII. USA: Grolier ncorporated.

[12]Lindgren, S. (2012). The Sociology of Media and nformation Technologies. n Aakvaag, G. C., Hviid Jacobsen, M. \& Johansson T. (Eds.), ntroduction to Sociology: Scandinavian Sensibilities. London: Pearson. London: Pearson. https://www.researchgate.net/profile/Simon Li ndgren/publication/269635704 The Sociology of Media and Information Technologies/link s/54911d2f0cf225bf66a9a03f.pdf

[13]Fiske, J. (2010). Understanding popular culture. Routledge.

http://people.southwestern.edu/ bednarb/criti cal-cultural/articles/fiske.pdf

[14]Bullock, A. \& Trombley, A. (1998). The Harper Dictionary of Modern Thought. USA: Harper

[15] Albarracin, D \& Sunderrajan, A., Lohmann, S \& Chan, Man-Pui Sally. (2018). The Psychology of attitudes, motivation, and persuasion, $n$ Albarracin \& Johnson (Eds.), Handbook of Attitudes. University of llinois.

https://www.researchgate.net/publication/3251 14721_The Psychology_of_Attitudes_Motivatio $\underline{\mathrm{n} \text { and Persuasion In Albarracin Johnson Eds }}$ Handbook of Attitudes

[16]Jowett, G. S., \& O'donnell, V. (2018). Propaganda \&persuasion. Sage publications.

https://people.ucalgary.ca/ rseiler/jowett.htm

[17]Halling, S. S. (2015). Propaganda Powers Social Reform: The Visual Rhetoric of Lewis Hine, Dorothea Lange, and Norman Rockwell. All
Graduate Theses and Dissertations. 4253. https://digitalcommons.usu.edu/etd/4253

[18]Szanto, G. H. (1978). Theater \& Propaganda. New York: University of Texas Press.

[19]Abdullah, M., \& Nadvi, M. J. (2011). Understanding the principles of slamic worldview. Dialogue (Pakistan), 6(3).

http://www.academia.edu/download/43283923 /Dialogue July September2011 268-289.pdf

[20]Kroon, S. \& Kurvers, J. (2016). Language use, language attitudes and dentity $\mathrm{n}$ the East Timorese diaspora $\mathrm{n}$ the Netherlands. Journal of Multilingual and Multicultural Development, Vol. 41 (5), p. 444-456.

https://doi.org/10.1080/01434632.2019.165787 $\underline{2}$

[21]Strauss, A, \& Corbin, J. (1990). Basic of Qualitative Research: Grounded Theory: Procedures and Techniques. Newbury Park, CA: Sage Publications, nc.

[22]Jacobs, J. A. (2013). American Studies: A Case Study of nterdisciplinarity. University of Pennsylvania.

https://repository.upenn.edu/cgi/viewcontent.c gi?article $=1049 \&$ context $=$ psc working papers 